\title{
Integration of Science learning Apps based on Inquiry Based Science Education (IBSE) in enhancing Students Science Process Skills (SPS)
}

\author{
https://doi.org/10.3991/ijim.v14i09.11706 \\ Mohd Munir Baharom $\left({ }^{\square}\right)$ \\ Jabatan Pendidikan Negeri Johor, Johor Bahru, Malaysia \\ munir.baharomemoe.gov.my \\ Noor Azean Atan, Mohd Shafie Rosli, Sanitah Yusof, \\ Mohd Zolkifli Abd Hamid \\ Universiti Teknologi Malaysia, Skudai, Malaysia
}

\begin{abstract}
The teaching and learning process no longer has its focus on the classroom. There are various teaching methods which teachers can use these days. However, the traditional, passive and teacher-oriented methods of teaching Science are still being widely used and this has led to the deterioration of students' interest in Science. Thus, this study was conducted to examine the effectiveness of Inquiry Based Science Education (IBSE) learning through apps in improving the level of students' mastery and achievement in the Science Process Skills (SPS). The study involved a total of 30 Year-6 students from a school in the district of Johor Bahru selected based on the their achievement in the Primary School Achievement Test. It took 5 weeks to complete the study which used quasi-experimental design of time series design followed by multiple repetitions of assessments before the post-test was given to the students. The results of the paired-samples $t$-test were found to be significant $(t=-11.119$, df $=29, \mathrm{p}<.05$ ) which showed that, there was a difference in the level of the students' performance in the pre- and post-tests. The quasi-experimental study of this series of time design used recurring measurements carried out on dependent variables and one-way ANOVA tests for repeated measures were used for the data analysis. The test results of Mauchly's Test of Sphericity showed that, there were significant differences in the three test scores $F(1.63,47.4)=344, p<.05$. The mean score values for test 2 , test 3 and test 4 outweighed the mean of test 1 . In addition, the graphical shape of plots profile shows that, teaching activities through apps enhanced students' Science Process Skills (SPS). Therefore, it can be concluded that, the integration of Inquiry-Based Science Education (IBSE) in Science learning through Apps is capable of improving students' mastery and achievement in their Science Process Skills (SPS)
\end{abstract}

Keywords - Mobile Learning; Science Process Skills (KPS); Inquiry Based Science Education (IBSE) 


\section{Introduction}

The use of apps fulfils the requirements of Shift 7 in the Malaysian Education Development Plan (MEDP) 2013-2025 (Preschool to Post-Secondary Education), which leverages information technology (ICT) to improve the quality of learning in Malaysia. The optimum use of ICT in self-learning can be extended for access to high quality teaching, regardless of the location or level of students' skills [29]. As such, the implementation of new initiatives is highly anticipated by the society to continue its success and impact in making education in Malaysia well in tandem with that of other developed countries. Considering the needs of today's environment and technology, various forms of ICT integration, including apps have been introduced, where the learning process can be carried out by integrating it with mobile technology such as laptops, tablets and smartphones. The use of apps will revolutionize education in schools and transform conventional classrooms into interactive classrooms with applications which have the potential to enhance students' learning experience to explore, examine, investigate and conduct activities or experiments which they need to master [53]. Therefore, to help students think critically and build their confidence in problem solving, the hands-on approach and the minds-on approach in the inquirybased learning environment need to be integrated [6].

Therefore, to continue its legacy as a rapidly developing country towards becoming a developed country, the education sector needs to be developed and a paradigm shift taken [30]. Accordingly, a research that supports the development of skills and the development of knowledge needs to be developed and implemented through the use of mobile technology to enhance student's mastery of the Science Process Skills (KPS) by integrating an inquiry-based approach which can support towards improving students' understanding and their subsequent mastery of skills [5], [16], [47], [55]. Overall, the use of apps in an inquiry-based learning environment is deemed capable of helping students in self-directed learning and exploration, which is considered as an important component of education in the 21st century. In support of this goal, the provision of apps helps teachers to design and implement learning outside of the traditional classroom [3]. The learning environment with the use of multimedia on mobile platforms and inquiry-based learning combined, can help enhance students' understanding, thereby supporting the mastery of Science Process Skills (SPS) in Science subjects [53].

\subsection{Background of problems}

A study by the Inspectorate and Quality Assurance Committee (IQAC) 2011 found that, only $13 \%$ of teachers in schools achieved good or excellent grades in teaching sessions delivered using pedagogical best practices, while the remaining $87 \%$ of them did not practice proper pedagogy when teaching and learning. Overall, it was found that, teachers' achievements are still at a low level and are a cause for concern, thus the need for them to improve their pedagogical skills [6], [7]. Meanwhile, in a report issued by the Teacher Education Division, the Ministry of Education (MOE) to the State Education Department, it was stated that the results of their study found that, $42.4 \%$ of 
students stated that Science teachers use the lecture method almost all the time in the class. The study was conducted in a total of 113 schools across Malaysia and it was found that, the percentage of teachers surveyed who used creative teaching techniques, such as debate $(24 \%)$, simulation ( $45 \%$ ), games $(45 \%)$, model building $(52 \%)$, projects $(53 \%)$ and field studies (57\%) were relatively low. The most notable finding was that, more than $89.29 \%$ of Science teachers used teaching techniques that did not impress students and involved only copying notes. This situation causes students to lose interests in studying Science as their main focus and objective are to memorize the content of the study and pass the examinations. Students only listen to explanations given by teachers and are not exposed to Science Process Skills (SPS), thus resulting in their cognitive levels to not fully develop. This consequently leads to their failure to construct and to get the grasp of the Science concept. Inaccurate interpretations of students' abilities cause students to not collaborate with each other resulting in less communication and less teamwork among them [45]. This situation contributes to the students' failure to master the concept of Science and this in turn causes them to become disinterested in the Science subjects. This factor causes a decline in their performance, rendering it difficult to produce high quality students.

The Primary School Science Curriculum in Malaysia focuses on the mastery of scientific skills in learning and understanding of nature [12], [39], [54]. These Scientific skills are an important part of the inquiry process and problem solving for conducting activities based on scientific methods. These Scientific Skills are divided into two components, namely, Science Process Skills (SPS) and Manipulative Skills (MS). Science Process Skills (SPS) is divided into two elements, namely Basic Science Process Skills and Integrated Science Process Skills, which enable students to be trained through activities and investigations, and these skills range from the simplest to the most complex [34]. Inquiry allows students to participate in Science activities and exercises as well as encouraging them to study Science [41], [3], [13]. Students should be actively engaged in teaching and learning activities and be able to voice their opinions easily. However, this is not the case, because students are passive and only wait for teachers' instructions in the classroom [24], [37], [44]. Therefore, to ensure that students gain optimum knowledge, the integration of mobile technology in teaching and learning should not be underestimated as a quality learning process is believed to be capable of producing knowledgeable and excellent students (58), [33]. However, no analysis or study of the effectiveness of mobile learning methods for Science subjects in Malaysia has been conducted. Mobile learning (apps) is a concept of learning that emphasizes on teachers' ability to carry out the learning process without being constrained by the physical locations of the learning process [28], [50].

\subsection{Literature review}

The Science teaching method in primary schools is one of the main causes for the failure listed in the Primary School Standard Curriculum, and it also causes students to lose interest in Science subjects in primary schools. Teachers rarely conduct learning activities such as simulation, project, inquiry, experiment, discussion, visit, use of external resources and the use of technology and this has contributed to the decline of 
students' achievement in Science subjects [13]. Teachers' failure to apply constructivism as a method of learning has resulted in students not being able to form their own understanding in constructing analogies, examples and methods of digesting what they have learned in their own way [3]. Students are less interested in Science due to the teaching methods practised by teachers in the teaching and learning process of Science which are unable to draw their attention [1], [18], [27], [53], [57], [59]. Teachers only teach using traditional methods by giving descriptions and writing on the chalkboards. Although the concepts of contextual learning, mastery learning, inquiry and constructivism have been written in the Daily Lesson Plan, they are not fully implemented [48]. To address the problem of exam-based teaching and learning delivery methods, teacher-designed learning techniques should suit the various levels of the students' brainpower and be able to arouse their interest in learning Science topics easily and effectively [18], [27], [53], [57], [59]. Thus, it can be concluded that teaching methods and techniques play important roles in the teaching and learning process, where Science learning should be able to get students engaged in the teaching and learning process and even should enable them to identify problems, design problem solving methods and find solutions to such problems as in the Inquiry-Based Science Education (IBSE) strategy [25], [44], [46], [1], [23].

\subsection{Inquiry-Based Science Education (IBSE)}

An inquiry approach helps students think critically and build confidence in solving problems [3]. Referring to Table 1, the learning level of inquiry is divided into four types; verification inquiry, structured inquiry, guided inquiry and open inquiry. Verification inquiry is the first and the lowest level, where students verify a principle or law of Science, which final results are known. In structured inquiry, students investigate the questions raised by teachers based on the prescribed procedures. Students conduct investigations based on questions given by the teacher, but planning and procedures are determined by the students themselves through the third level of guided inquiry, while in the fourth level, namely, open inquiry, which is the highest level, students are required to ask questions and determine how the investigation should be conducted. Inquiry-based Science Education utilizes and promotes the use of Science Process Skills (SPS) in Science activities carried out, which simultaneously builds and nurtures students' curiosity and awe of the phenomena observed in everyday life [35], [56]. Ergül et al. (2011) in their study found that, teaching of Science based on inquiry enabled students to integrate Science Process Skills (SPS), scientific reasoning and critical thinking to build their understanding of scientific concepts [15]. Students engaged in the study of Science based on inquiry are able to build a deeper understanding including appreciating knowledge and discovery process in Science. The advantage of the Science inquiry approach is that, it is driven by the curiosity and desire to understand something or to solve problems, which in turn raises questions to be solved [48]. Inquiry learning emphasizes on the exploration of the environment and is able to stimulate students to explore further to enhance their understanding and achievements [56]. In addition, interesting inquiry activities can help develop skills in discussion, communications and recording learning [38], [4]. The integrated IBSE 
approach coupled with the use of mobile applications will make Science learning more meaningful and effective.

Table 1. Four Levels of Inquiry Learning

\begin{tabular}{|c|l|l|}
\hline Level & \multicolumn{1}{|c|}{ Types of Inquiry } & \multicolumn{1}{c|}{ Description } \\
\hline 4 & Open Inquiry & $\begin{array}{l}\text { Students do research based on the questions and steps which they } \\
\text { themselves create and determine according to specific topics. }\end{array}$ \\
\hline 3 & Guided Inquiry & $\begin{array}{l}\text { Students conduct investigations based on the questions which the teacher } \\
\text { has prepared, and the selection of the exploration steps is determined by } \\
\text { them. }\end{array}$ \\
\hline 2 & Structured Inquiry & $\begin{array}{l}\text { Students conduct research based on questions and steps which the teacher } \\
\text { has determined. }\end{array}$ \\
\hline 1 & Verification & $\begin{array}{l}\text { Students verify certain principles based on the teacher's explanations and } \\
\text { the results of the research are known in advance. }\end{array}$ \\
\hline
\end{tabular}

\section{$1.4 \quad$ Mobile learning}

Mobile learning generally uses technology components such as laptops, digital personal aids and mobile phones. It enables students to share information more easily, facilitates the process of assigning tasks faster and can build good co-operation among group members [11], [10], [36], [26], [51], [52]. Students can share notes via mobile devices, such as cell phones and smartphones and they no longer have to sit in front of a personal computer to download notes [32], [21]. Good acceptance of mobile learning among students enables them to use mobile learning platforms for communication, collaboration and self-learning opportunities [49], [17]. Educators need to be prepared in terms of pedagogy and approaches in applying the use of mobile technology during the teaching and learning process [17]. Teachers' skills in the use of mobile technology need to be enhanced, so that teachers can produce themselves, for example, software that are now readily available and can be developed using simple programming techniques to prepare quiz questions, and this can greatly enhance students' knowledge of Science Process Skills (SPS) [40]. In fact, mobile devices make teaching and learning easier because all relevant information can be implemented in a timely manner. Students understand Science learning better after using mobile technology compared to traditional learning. Mobile learning can also save time and make it easier for students and teachers to set their daily schedule without being limited to specific times.

\subsection{Science Process Skills (SPS)}

Science process skills (SPS) is a skill that encourages students to question Science problems which they encounter and to find the answers systematically [14], [20], [24], [9], [43], [19], [8]. Based on Diagram 1 below, Science Process Skills (SPS) can be divided into two types, namely, Basic Science Process Skills and Integrated Science Process Skills. Basic Science Process Skills include the skills of observing, classifying, measuring and using numbers, inferring, predicting, communicating and using space and time relationships. Meanwhile, Integrated Science Process Skills consists of skills in interpreting information, operating definitions, controlling variables, hypothesizing 
and experimenting. Science Process Skills (SPS) are very useful in designing and constructing scientific facts in Physical science at the school level and scientific activities which involve a variety of methods, including such activities as observing phenomena, questioning, scrutinizing, examining books and also other sources of information to find out about the phenomenon [34], [42].

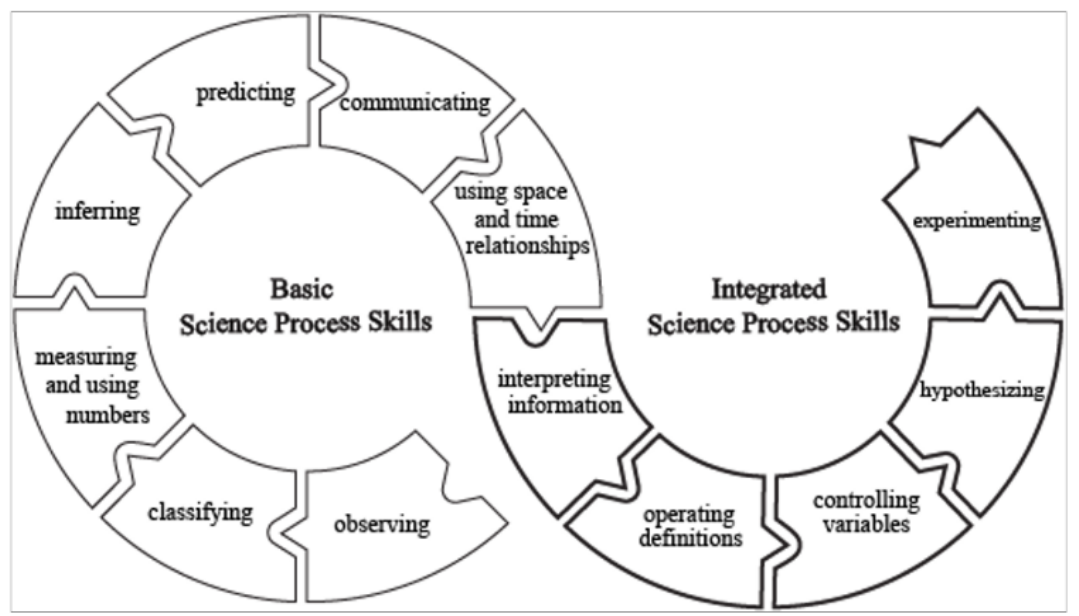

Fig. 1. Basic and Structured Science Process Skills

\section{Objectives of the Study}

The objectives of the study as outlined in the problem statement as which to study the impact of learning activities through apps based on the integration of Inquiry-based Science Education (IBSE) and the instructional scaffolding method in Science learning on:

i. The level of students' achievement in Science learning.

ii. The level of mastery of Basic and Integrated Science Process Skills.

\section{$3 \quad$ Methodology}

This study was conducted for 5 weeks using the quasi-experimental design of time series design. The study involved a total of 30 Year-6 students from a school in the district of Johor Bahru, selected based on the achievement in the Primary School Achievement Test. The quasi-experimental study of this series of time designs used recurring measurements which were carried out on dependent variables and one-way ANOVA tests for repeated measures were used for the data analysis. 


\section{$4 \quad$ Data Analysis and Results}

The comparative analysis of the frequency of the content-based pre- and post-test scores as in Fig. 2 shows that, out of the total 30 students taking the test, there were 27 of them who showed an increase in test scores, $90 \%$ of the overall test scores.

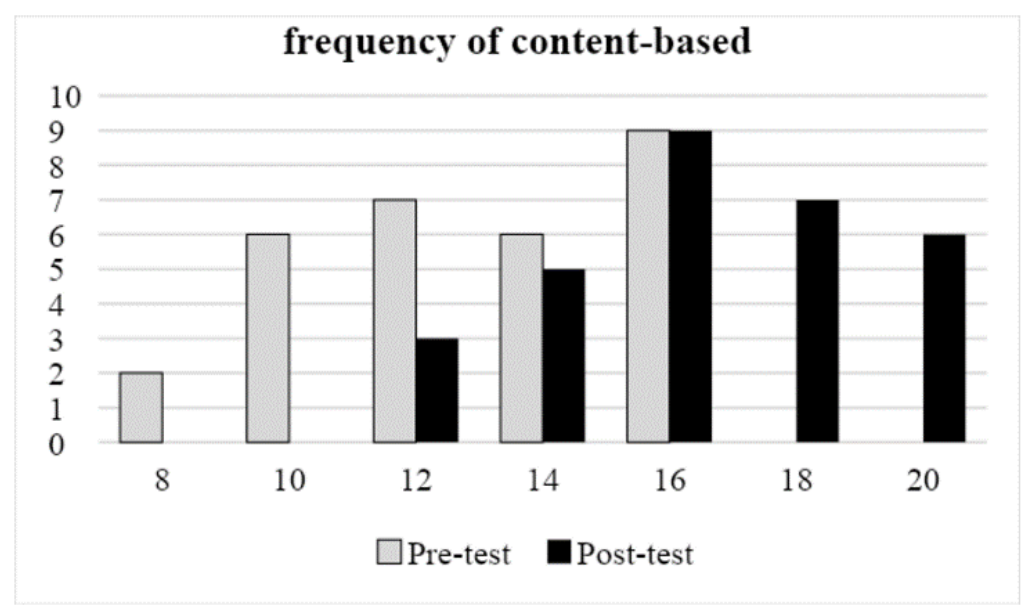

Fig. 2. Comparison of the frequency of content-based pre- and post- test scores

Table 2. Statistical results of paired-sample $t$ test for pre- and post-tests

\begin{tabular}{|l|c|c|c|c|}
\hline \multicolumn{1}{|c|}{ Pairs } & Mean & Standard Deviation & t & $\begin{array}{c}\text { Sig. } \\
\text { (2-tailed) }\end{array}$ \\
\cline { 1 - 3 } Pre-Test & 32.93 & 2.612 & & \multirow{2}{*}{-11.119} \\
\cline { 1 - 3 } Post-Test & 36.53 & 2.515 & .000 \\
\hline Post-Test- Pre-Test & 3.6 & & & \\
\hline
\end{tabular}

To study the comparisons of the students' achievements, further analyses were performed using the $t$-test for repeated measures (paired-samples $t$ test). Based on Table 2 , the results of the study were significant $(\mathrm{t}=-11.119, \mathrm{df}=29, \mathrm{p}<.05)$. This indicates that, there were significant differences in students' achievement in pre- and post-tests at 32.93 and 36.53, respectively. Higher mean scores in post-test with a difference of 3.6 indicate that, the use of apps in teaching and learning Science can improve students' achievement. 


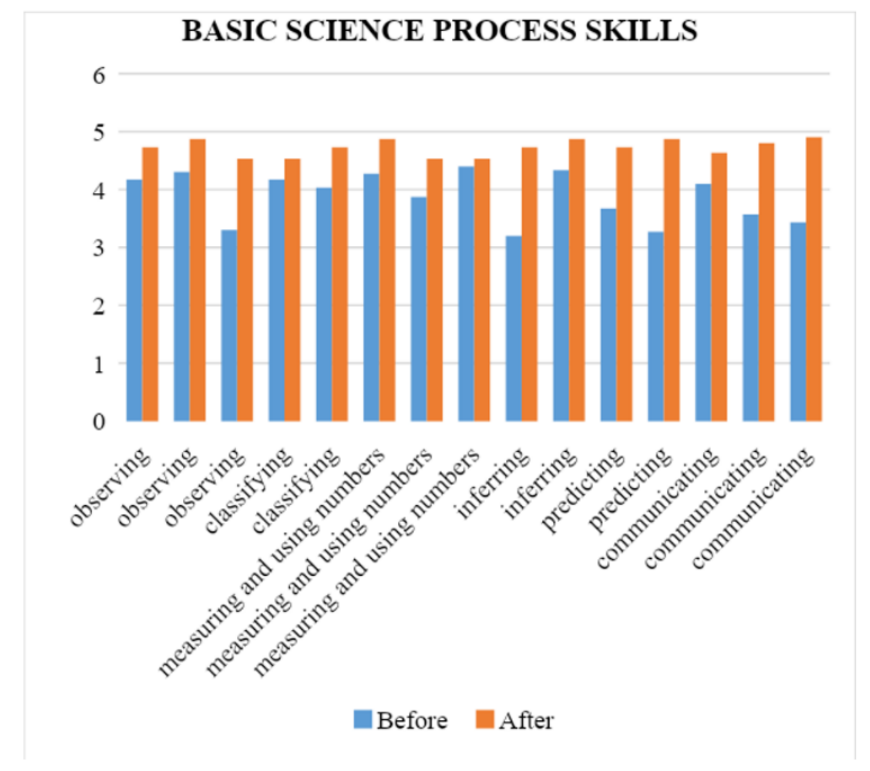

Fig. 3. Comparison of the means before and after the use of apps for the Basic SPS

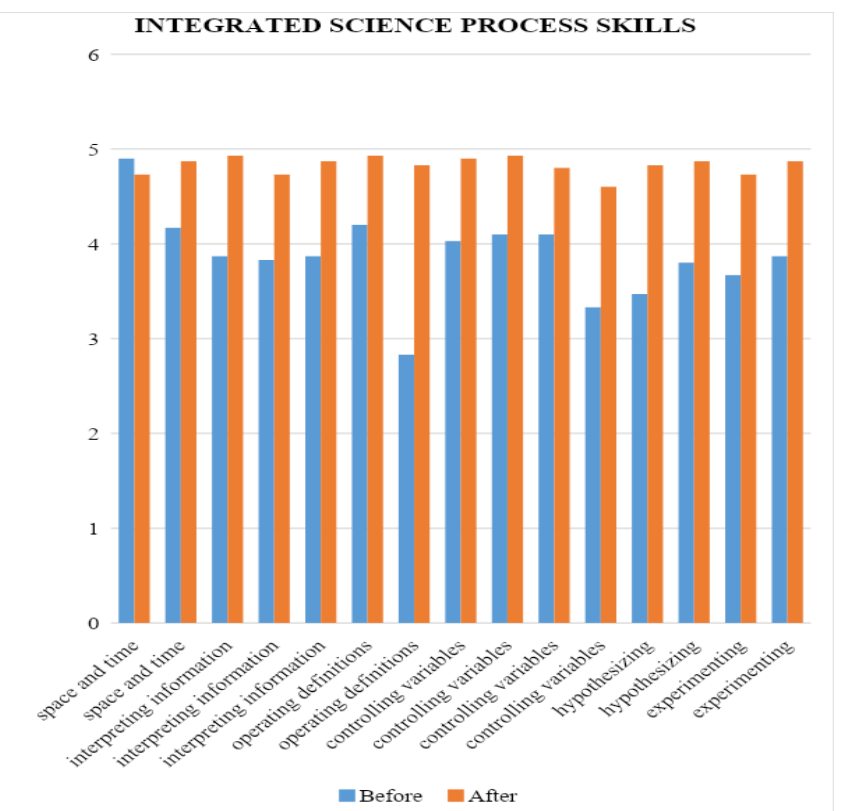

Fig. 4. Comparison of the means before and after the use of apps for the Integrated SPS

The subsequent analysis was to find the mean difference in students' achievement before and after they used the apps in the learning session. 
Table 3. Comparison of students' achievement for Science Process Skills (SPS) test

\begin{tabular}{|c|c|c|c|c|c|c|c|c|c|c|}
\hline STU-DENTS & SPS1 & \% & SPS2 & \% & SPS3 & \% & SPS4 & \% & TOTAL & PERCENT \\
\hline S1 & 6 & 43 & 7 & 50 & 9 & 50 & 12 & 67 & 34 & 53 \\
\hline S2 & 7 & 50 & 7 & 50 & 12 & 67 & 15 & 83 & 41 & 64 \\
\hline S3 & 8 & 57 & 9 & 64 & 13 & 72 & 17 & 94 & 47 & 73 \\
\hline S4 & 7 & 50 & 9 & 64 & 13 & 72 & 17 & 94 & 46 & 72 \\
\hline S5 & 6 & 43 & 7 & 50 & 12 & 67 & 15 & 83 & 40 & 63 \\
\hline S6 & 9 & 64 & 10 & 71 & 14 & 78 & 17 & 94 & 50 & 78 \\
\hline S7 & 12 & 86 & 11 & 79 & 13 & 72 & 17 & 94 & 53 & 83 \\
\hline S8 & 6 & 43 & 7 & 50 & 11 & 61 & 15 & 83 & 39 & 61 \\
\hline S9 & 5 & 36 & 7 & 50 & 11 & 61 & 16 & 89 & 39 & 61 \\
\hline S10 & 6 & 43 & 7 & 50 & 11 & 61 & 15 & 83 & 39 & 61 \\
\hline S11 & 12 & 86 & 13 & 93 & 15 & 83 & 17 & 94 & 57 & 89 \\
\hline S12 & 9 & 64 & 9 & 64 & 14 & 78 & 17 & 94 & 49 & 77 \\
\hline S13 & 9 & 64 & 10 & 71 & 11 & 61 & 15 & 83 & 45 & 70 \\
\hline S14 & 9 & 64 & 11 & 79 & 11 & 61 & 16 & 89 & 47 & 73 \\
\hline S15 & 10 & 71 & 11 & 79 & 14 & 78 & 17 & 94 & 52 & 81 \\
\hline S16 & 6 & 43 & 7 & 50 & 9 & 50 & 13 & 72 & 35 & 55 \\
\hline S17 & 7 & 50 & 7 & 50 & 10 & 56 & 14 & 78 & 38 & 59 \\
\hline S18 & 9 & 64 & 10 & 71 & 12 & 67 & 15 & 83 & 46 & 72 \\
\hline S19 & 11 & 79 & 13 & 93 & 14 & 78 & 17 & 94 & 55 & 86 \\
\hline S20 & 10 & 71 & 11 & 79 & 13 & 72 & 17 & 94 & 51 & 80 \\
\hline S21 & 11 & 79 & 11 & 79 & 13 & 72 & 17 & 94 & 52 & 81 \\
\hline S22 & 13 & 93 & 14 & 100 & 13 & 72 & 17 & 94 & 57 & 89 \\
\hline S23 & 12 & 86 & 11 & 79 & 14 & 78 & 17 & 94 & 54 & 84 \\
\hline S24 & 6 & 43 & 7 & 50 & 10 & 56 & 15 & 83 & 38 & 59 \\
\hline S25 & 6 & 43 & 7 & 50 & 11 & 61 & 14 & 78 & 38 & 59 \\
\hline S26 & 9 & 64 & 10 & 71 & 14 & 78 & 17 & 94 & 50 & 78 \\
\hline S27 & 4 & 29 & 7 & 50 & 11 & 61 & 14 & 78 & 36 & 56 \\
\hline S28 & 6 & 43 & 7 & 50 & 11 & 61 & 15 & 83 & 39 & 61 \\
\hline S29 & 9 & 64 & 9 & 64 & 12 & 67 & 15 & 83 & 45 & 70 \\
\hline S30 & 4 & 29 & 7 & 50 & 11 & 61 & 14 & 78 & 36 & 56 \\
\hline & & & & & & & & & \\
\hline
\end{tabular}

The analysis on the Science Process Skills (SPS) test showed an increase in students' achievement, where all the four tests showed that $27 \%$ of them achieved higher than 80 marks, while $50 \%$ of them achieved scores in the range of $60-78$.

Table 4. Mauchly's Test of Sphericity

\begin{tabular}{|l|c|c|c|c|c|c|c|}
\hline $\begin{array}{c}\text { Within Subjects } \\
\text { Effect }\end{array}$ & Mauchly's W & $\begin{array}{c}\text { Approx. Chi- } \\
\text { Square }\end{array}$ & df & Sig. & & \multicolumn{4}{|c|}{$\begin{array}{c}\text { Epsilon } \\
\text { Green-house- } \\
\text { Geisser }\end{array}$} & $\begin{array}{c}\text { Huynh- } \\
\text { Feldt }\end{array}$ & $\begin{array}{c}\text { Lower- } \\
\text { bound }\end{array}$ \\
\hline Tests & .236 & 40.066 & 5 & .000 & .520 & .545 & .333 \\
\hline
\end{tabular}

For comparisons of the achievements of the SPS test, repeated measures of one-way ANOVA tests were conducted. The results of Mauchly's Test of Sphericity as shown in Table 4 are significant, so these need to be modified to adjust the new df values by the adjustment of the df values using Tests of Within-Subjects Effects, such as in Table 5, 
with the new values (new $\mathrm{df} 1=1.634$, new $\mathrm{df} 2=47,382$ ). Based on the new df values, it clearly shows that there was a significant difference in the KPS test score [F $(1.63,47.4)=344, p<.05]$ overall among the four tests.

Table 5. Tests of Within-Subjects Effects

\begin{tabular}{|c|l|c|c|c|c|c|}
\hline \multicolumn{2}{|c|}{ Source } & $\begin{array}{c}\text { Type III Sum of } \\
\text { Squares }\end{array}$ & df & Mean Square & F & Sig. \\
\hline \multirow{5}{*}{ Tests } & Sphericity Assumed & 1026.467 & 3 & 342.156 & 344.001 & .000 \\
\cline { 2 - 7 } & Greenhouse-Geisser & 1026.467 & 1.561 & 657.554 & 344.001 & .000 \\
\cline { 2 - 7 } & Huynh-Feldt & 1026.467 & 1.634 & 628.250 & 344.001 & .000 \\
\cline { 2 - 7 } & Lower-bound & 1026.467 & 1.000 & 1026.467 & 344.001 & .000 \\
\hline \multirow{5}{*}{ Error(test) } & Sphericity Assumed & 86.533 & 87 & .995 & & \\
\cline { 2 - 8 } & Greenhouse-Geisser & 86.533 & 45.270 & 1.911 & & \\
\cline { 2 - 8 } & Huynh-Feldt & 86.533 & 47.382 & 1.826 & & \\
\cline { 2 - 8 } & Lower-bound & 86.533 & 29.000 & 2.984 & & \\
\hline
\end{tabular}

Table 6. Estimated Marginal Means

\begin{tabular}{|c|c|c|c|c|}
\hline \multirow{2}{*}{ Test } & \multirow{2}{*}{ Mean } & \multirow{2}{*}{ Std. Error } & \multicolumn{2}{|c|}{ 95\% Confidence Interval } \\
\cline { 4 - 5 } & & & Lower Bound & Upper Bound \\
\hline 1 & 8.133 & .457 & 7.199 & 9.067 \\
\hline 2 & 9.100 & .396 & 8.289 & 9.911 \\
\hline 3 & 12.067 & .291 & 11.471 & 12.663 \\
\hline 4 & 15.633 & .260 & 15.101 & 16.166 \\
\hline
\end{tabular}

The mean score values of the SPS tests for test $2(\operatorname{Min}=9.10)$, test $3(\operatorname{Min}=12.01)$ and test $4(\operatorname{Min}=15.63)$ are higher than that for test score $1(\operatorname{Min}=8.13)$, as shown in Table 6, indicating that the use of apps in teaching and learning is effective to enhance students' achievement and mastery of Science Process Skills in the study population. In addition, the graphical form of profile plots in Fig. 5 clearly indicates that, the integration of apps in teaching and learning activities has helped to improve students' achievement in the KPS 2, KPS 3 and KPS 4 tests.

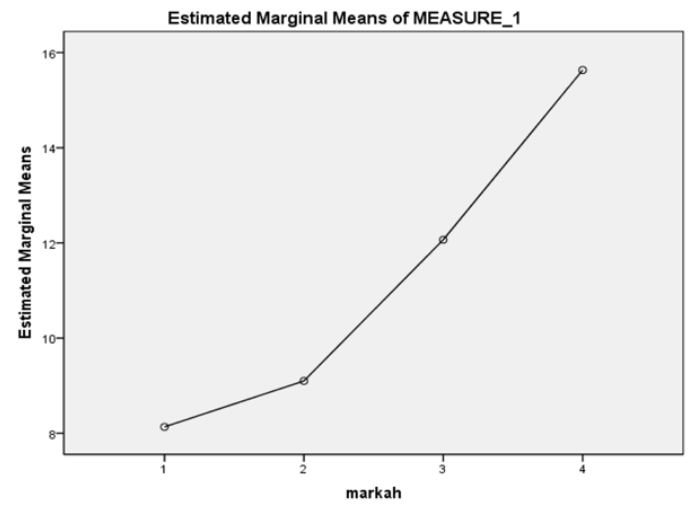

Fig. 5. Graphs of Profile plots 


\section{Discussion}

Comparisons of the frequency of scores shown in Figure 1 and the means in Table 1 , between the pre and post content-based tests show that, the majority of respondents recorded improved scores in post-tests. This proved the effectiveness of IBSE integration through apps, which has successfully enhanced the level of students' achievement after using the app. In fact, the increased means in the achievement of Basic SPS in Figure 3 and Integrated SPS in Figure 4 show that, the effectiveness of using mobile technology depends on good acceptance among students [49]. Therefore, the researchers recommend that educators be prepared in terms of pedagogy and approaches in applying the use of mobile technology in teaching and learning. The increase in scores also accentuates the facts that learning through mobile technology is more effective, efficient and is able to encourage students to learn [32].

From the comparative analysis of students' achievement for the Science Process Skills (SPS) tests shown in Table 3, the improvements in their achievements were significant, where the overall percentages for all the three tests showed that, the majority of the students achieved scores above 80 marks. Each student has different potentials, so learning using mobile technology is a motivation for the students to continuously improve their achievement in education and positively impact their Science learning [22]. In fact, the improved achievement and mastery of the students in SPS, as can be seen in Figure 5, proves that a more flexible mobile learning can make learning more individual and student-centred, as well as making them creative and critical, compared to traditional learning [2], [31].

\section{Conclusion}

In conclusion, learning through apps can have a positive impact as it enables students to understand Science learning better after using mobile technology compared to traditional learning [49]. Overall, it was found that, all of the respondents not only showed improvements in their understanding of Basic and Integrated Science Process Skills, but also in their overall achievements. Therefore, the integration of mobile technology through the IBSE approach in Science learning is highly recommended as it helps to increase students' mastery of Science Process Skills.

\section{$7 \quad$ References}

[1] Abd Rahman Ismail (2003). Kefahaman Konsep Sains dan Perhubungannya dengan Tahap Kognitif dan Jantina Pelajar Tingkatan 3. Tesis Sarjana, UM.

[2] Abd-El-Khalick, F., Boujaoude, S., Duschl, R., Lederman, N. G., Mamlok-Naaman, R., Hofstein, A., Tuan, H. L. (2004). Inquiry in science education: International perspectives. Science Education, 88(3), 397-419. https://doi.org/10.1002/sce.10118

[3] Ahmed, S., \& Parsons, D. (2013). Abductive science inquiry using mobile devices in the classroom. Computers \& Education, 63, 62-72. https://doi.org/10.1016/j.compedu.2012. $\underline{11.017}$ 
[4] Anderson. R.D. (2002). Reforming science teaching: What research say about inquiry. Journal of Science Teacher Education, 13(1), 1--12.

[5] Alberta, Branch, J., \& Oberg, D. (2004). Focus on Inquiry: A teachers' guide to implementing inquiry-based learning. Alberta Learning. Learning and Teaching Resources Branch.,119-128. Retrieved from http://ci.nii.ac.jp/naid/40016096677/\%5Cn http://education.alberta.ca/media/313361/focusoninquiry.pdf on 25 April 2012

[6] Bahagian Perancangan dan Penyelidikan Dasar Pendidikan. (2012). Pelan Strategik Interim Kementerian Pelajaran Malaysia 2011 - 2015. Kementerian Pelajaran Malaysia. Retrieved from http://www.moe.gov.my/pdf/Pelan Strategik Interim KPM 2011-2020.pdf

[7] Bahagian Pembangunan Pendidikan (2016). Panduan Perlaksaan Pengajaran dan Pembelajaran Berasaskan Inkuiri. Kuala Lumpur

[8] Bulent, A. Mehmet, E. \& Nuran, E. (2014). The investigation of science process skills of elementary school teachers in terms of some variables: Perspectives from Turkey. AsiaPacific Forum on Science Learning and Teaching, Volume 15, Issue 1.

[9] Bybee, R.W., \& DeBoer, C. E. (2001). Research on goals for the science curriculum. In Gabel (4.eds.), Handbook of Research on Science Teaching and Learning. (pp. 357-387). National Science Teachers Association, New York: USA

[10] Coil, R. A. (1998). Multiple intelligences and computer-assisted learning with adult learners: An examination of learner outcomes. Disertasi kedoktoran, The Union Institute University. Dissertation Abstracts International, 58(121), 4523A

[11] Chien, Cheng-Chih (1997). The effectiveness of interactive computer simulations on college engineering students' conceptual understanding and problemsolving ability related to circular motion. Disertasi kedoktoran, The Ohio State University. Dissertation Abstracts International, 58(07),2589A.

[12] Dayana Farzeeha Ali, Lee Yee, C., \& Mohd Nur Khafiz Hussin. (2014). Persepsi Guru-Guru Terhadap Sistem KBSR dan KSSR: Satu Tinjauan Dari Aspek Kurikulum, Kesedian Guru Dan Pelaksanaannya. Prosiding Persidangan Antarabangsa Kelestarian Insan, 2014(April), 205-212. https://doi.org/10.21009/bahtera.131.07

[13] Drăghicescu, L. M., Cristea, S., Petrescu, A.-M., Gorghiu, G., \& Gorghiu, L. M. (2015). The Learning to Learn Competence - Guarantor of Personal Development. Procedia - Social and Behavioral Sciences, 191, 2487-2493. https://doi.org/10.1016/j.sbspro.2015.04.571

[14] Dillashaw, F.G., \& Okey, J.R. (1980). Test of Integrated Science Process Skills for Secondary Students. Science Education, 64, 601-608. https://doi.org/10.1002/sce.3730 $\underline{640506}$

[15] Ergül, R., Sevgül CALI, Y., \& Özdlek, Z. (2011). the Effects of Inquiry-Based Science Teaching on Elementary School Students' Science Process Skills and Science Attitudes. Bulgarian Journal of Science and Education Policy, 5(1), 48-68.

[16] Harlen, W. (2013). Assessment \& Inquiry-Based Science Education: Issues in Policy and Practice. In Book.

[17] Khaddage, F., Müller, W., \& Flintoff, K. (2016). Advancing mobile learning in formal and informal settings via mobile app technology: Where to from here, and how? Educational Technology and Society, 19(3), 16-26.

[18] Freeman, S., Eddy, S. L., McDonough, M., Smith, M. K., Okoroafor, N., Jordt, H., \& Wenderoth, M. P. (2014). Active learning increases student performance in science, engineering, and mathematics. Proceedings of the National Academy of Sciences of the United States of America, 111(23), 8410-8415. https://doi.org/10.1073/pnas.13190 $\underline{30111}$

[19] Fullan, M. (2007). Teachers and school characteristics and their influences on science curriculum implementation. Journal of Research in Science Education, 44 (7), 883-907. 
[20] Germann, P. J., \& Aram, R. J. (1996). Student performances on the science processes of recording data, analyzing data, drawing conclusions, and providing evidence. Journal of Research in Science Teaching, 33(7), 773-798. https://doi.org/10.1002/(sici)10982736(199609)33:7<773::aid-tea5>3.0.co;2-k

[21] Göksu, İ., \& Atici, B. (2013). Need for Mobile Learning: Technologies and Opportunities. Procedia - Social and Behavioral Sciences, 103, 685-694. https://doi.org/10.1016/ j.sbspro.2013.10.388

[22] Green, L. S., Hechter, R. P., Tysinger, P. D., \& Chassereau, K. D. (2014). Mobile app selection for 5th through 12th grade science: The development of the MASS rubric. Computers and Education, 75, 65-71. https://doi.org/10.1016/j.compedu.2014.02. $\underline{007}$

[23] Hanafi Jasman (2005). Salah Tanggapan Tentang Konsep Elektrik di Kalangan PelajarPelajar Tingkatan Enam Rendah di Daerah Kluang, Johor. Tesis Sarjana, UTM.

[24] Harlen, W. (1999). Purpose and procedures for assessing science process skills. Assessment in Education: principles, policy \& practice, 6(1), 129-144. https://doi.org/10. $\underline{1080 / 09695949993044}$

[25] Irfan Naufal Umar dan Sajap Maswan (2011). Aplikasi Pendekatan Inkuiri dalam Persekitaran Pembelajaran Berasaskan Web.

[26] Jimenez, J. E. et a1. (2003). Do the effects of computer-assisted practice differ for children with reading disabilities with and without IQ-achievement discrepancy. Journal of Learning Disbilities, 36(1), 34-37. https://doi.org/10.1177/00222194030360010501

[27] Jones, A., Buntting, C., Hipkins, R., McKim, A., Conner, L., \& Saunders, K. (2012). Defeloping Students' Futures Thinking in Science Education. Research in Science Education, 42(4), 687-708. https://doi.org/10.1007/s11165-011-9214-9

[28] Kukulska-Hulme, A., \& Traxler, J. (2005). Mudah alihe Learning: A Handbook for Educators and Trainers. London, UK: Routledge.

[29] Kementerian Pelajaran Malaysia. (2013) Pelan Pembangunan Pendidikan Malaysia 20132015 (Pendidikan Prasekolah hingga Lepas Menengah). Kuala Lumpur

[30] Kementerian Pelajaran Malaysia. (2015) Pelan Pembangunan Pendidikan Malaysia 20152015 (Pengajian Tinggi). Kuala Lumpur

[31] Khaddage, F., Lattemann, C., \& Bray, E. (2011). Mobile Apps Integration for Teaching and Learning. (Are Teachers Ready to Re-blend?). for Information Technology \& Teacher, 2545-2552. Retrieved from http://www.editlib.org/p/36694

[32] Khaddage, F., Müller, W., \& Flintoff, K. (2016). Advancing mobile learning in formal and informal settings via mobile app technology: Where to from here, and how? Educational Technology and Society, 19(3), 16-26.

[33] LeCun, Y., Bengio, Y., \& Hinton, G. (2015). Deep learning. Nature, 521(7553), 436-444. Retrieved from https://doi.org/10.1038/nature14539

[34] M.J. Padilla, J.R. Okey (1980) Test of the integrated science process skills for secondary science students Science Education, 64 (5) (1980), pp. 601-608. https://doi.org/10. $\underline{1002 / \text { sce. } 3730640506}$

[35] Nurshamshida Md Shamsudin, Nabilah Abdullah, \& Nurlatifah Yaamat. (2013). Strategies of teaching science using an Inquiry Based Science Education (IBSE) by novice chemistry teachers. Procedia - Social and Behavioral Sciences, 90(InCULT 2012), 583-592. https://doi.org/10.1016/j.sbspro.2013.07.129

[36] Nulden, U. (1999). Thematic modules in Asynchronous Learning Networks: A Scandinavian perspective on the design of introductory course. Journal of Group Decision and Negotiation, 85(5), 391-408. 
[37] Nik Zarini Nik Kar dan Salmiza Saleh (2012). Kesan pendekatan inkuiri penemuan terhadap pencapaian pelajar dalam mata pelajaran kimia. Asia Pacific Journal of Educators and Education, Vol. 27, 159-174.

[38] Nikolova, N., \& Stefanova, E. (2014). Inquiry-Based Science Education in Secondary School Informatics - Challenges and Rewards, 17-34. http://doi.org/10.1007/978-3-642$\underline{54338-8}$

[39] Norazilawati, A., Noraini, M. N., Mahizer, H., Nik Azmah, N. Y., \& Rumaizah, O. (2014). Kesediaan guru sains dan matematik dalam pelaksanaan kurikulum standard sekolah rendah 1. Jurnal Pendidikan Sains \& Matematik Malaysia, 4(1), 81-96. https://doi.org/10. 17576/jpen-2018-43.03-02

[40] Hussin, S., Radzi Manap, M., Amir, Z., \& Krish, P. (2012). Mobile Learning Readiness among Malaysian Students at Higher Learning Institutes. Asian Social Science, 8(12), 276283. https://doi.org/10.5539/ass.v8n12p276

[41] Olson, S. \& Louks-Horsley, S. (Eds.) (2000). Inquiry and the national science education standards: a guide for teaching and learning Washington: National Academies Press. Ostlund,

[42] Rahayu Johari (2008). Pengaruh Gaya Pengajaran Guru Cemerlang Fizik Terhadap Gaya Pembelajaran dan Pencapaian Matapelajarann Fizik Pelajar Tingkatan Empat. Tesis Sarjana, UKM.

[43] Rambuda, A.M., Fraser, W. J. (2004). Perceptions of teachers of the application of science process skills in the teaching of geography in secondary schools in the Free State province. South Afr. J. Educ. 24(1):10 - 17. https://doi.org/10.21125/iceri.2017.1764

[44] Rose Amnah abdul Rauf, Abd Rashid Johar, Lilia halim \& Siti Rahayah ariffin. (2013). Pemupukan Kemahiran Proses Sains di kalangan pelajar tingkatan dua di sekolah bestari. Jurnal Teknologi 40(E): 19-32 https://doi.org/10.11113/jt.v40.427

[45] Rosmawati Musa (2007). Pengesahan dan Penggunaan Ujian Matematik Tahun 4 Sekolah Rendah: Analisis Rasch. Tesis Doktor Falsafah, USM.

[46] Rojahan Hj. Abdullah (2004). Pencapaian dan Kesalahan Konsep dalam Kerja, Tenaga dan Kuasa di Kalangan Pelajar Tingkatan Lima Aliran Teknikal. Tesis Sarjana, UM

[47] Rutherford, F. J., \& Rutherford, J. (1964). The role of inquiry in science teaching. Journal of Research in Science Teaching, 2(2), 80-84. https://doi.org/10.1002/tea.3660020204

[48] Suduc, A.-M., Bizoi, M., \& Gorghiu, G. (2015). Inquiry Based Science Learning in Primary Education. Procedia - Social and Behavioral Sciences, 205, 474-479. https://doi.org/10. 1016/j.sbspro.2015.09.044

[49] Hussin, S., Radzi Manap, M., Amir, Z., \& Krish, P. (2012). Mobile Learning Readiness among Malaysian Students at Higher Learning Institutes. Asian Social Science, 8(12), 276283. https://doi.org/10.5539/ass.v8n12p276

[50] Sha, L., Looi, C. K., Chen, W., \& Zhang, B. H. (2012). Understanding mobile learning from the perspective of self-regulated learning. Journal of Computer Assisted Learning, 28(4), 366-378. https://doi.org/10.1111/j.1365-2729.2011.00461.x

[51] Sharples, M. (2000a). The design of personal mobile technologies for lifelong learning. Computers and Education, 34, 177-193. https://doi.org/10.1016/s0360-1315(99)00044-5

[52] Sharples, M et al. (2000b). Structured computer-based training and decision support in the Interpretation of neuroradiological images. International Journal of Medical Informatics, 60(30), 228-263.

[53] Stockwell, B. R., Stockwell, M. S., Cennamo, M., \& Jiang, E. (2015). Blended Learning Improves Science Education. Cell, 162(5), 933-936. https://doi.org/10.1016/j.cell. $\underline{2015.08 .009}$ 
[54] Tay Meng Guat, Kirar ak Sare, \& Litat Bilung. (2015). Kesediaan Pelajar Institusi Guru Dalam Pelaksanaan Kurikulum Standard Sekolah Rendah. Jurnal Penyelidikan IPG KBL, $12,1-18$.

[55] Trna, J., Trnova, E., \& Sibor, J. (2012). Implementation of inquiry-based science education in science teacher training. Journal of Educational and Instructional Studies in the World, (November), 199-209.

[56] Wang, P.-H., Wu, P.-L., Yu, K.-W., \& Lin, Y.-X. (2015). Influence of Implementing Inquiry-based Instruction on Science Learning Motivation and Interest: A Perspective of Comparison. Procedia - Social and Behavioral Sciences, 174, 1292-1299. https://doi.org/10.1016/j.sbspro.2015.01.750

[57] Waldrop, M. M. (2015). The science of teaching sciences. Nature, 523(7560), 272-274. https://doi.org/10.1177/019263655704122614

[58] Yu, L. D. and D. (2015). Deep learning. Nature Methods, 13(1), 35. https://doi.org/10. $\underline{1038 / \text { nmeth.3707 }}$

[59] Zohar, A., \& Dori, Y. J. (2003). Higher Order Thinking Skills and Low-Achieving Students: Are They Mutually Exclusive? Journal of the Learning Sciences, Vol. 12, pp. 145-181. https://doi.org/10.1207/s15327809j1s1202 1

\section{Authors}

Mohd Munir Baharom is a PHD student at at Faculty of Education, Universiti Teknologi Malaysia, 81310 UTM Skudai, Johor, Malaysia. Email: munir.baharom@moe.gov.my

Noor Azean Atan, Mohd Shafie Rosli, Sanitah Yusof \& Mohd Zolkifli Abd Hamid are senior lecturers at Faculty of Education, Universiti Teknologi Malaysia, 81310 UTM Skudai, Johor, Malaysia.

Article submitted 2019-09-19. Resubmitted 2020-03-27. Final acceptance 2020-03-30. Final version published as submitted by the authors. 